\title{
The Impact of SARS-CoV-2 variants on Morbidity, Mortality and Effectiveness of Vaccines
}

Kenan Midilli

Department of Clinical Virology, İstanbul Cerrahpaşa University School of Medicine, İstanbul, Turkey

C oronaviruses are known to evolve slower than the other RNA viruses; however, SARS-CoV-2 underwent a major shift through D614G change in February 2020, even before the declaration of a pandemic by WHO and D614G variant became rapidly dominant throughout the world. The spike protein of this variant with D614G change have a higher affinity to human ACE-2 and gained a transmission advantage against other circulating variants. Some mutations may confer advantages for the virus, and the variants carrying this kind of mutations may outcompete the previous variants (1). A mutation may cause changes in biology, transmissibility, susceptibility of the virus against naturally or vaccine-induced immunity, and the presentation and outcome of the disease caused by the virus. All of these changes may pose extra challenges regarding the containment of the epidemic, treatment and prevention of the disease using antivirals, immunotherapeutics like monoclonal antibodies or convalescent plasma, and vaccines $(2,3)$.

Towards the end of 2020, amid the second peak of the COVID, several new variants emerged within a short period. A variant that was detected first in September 2020 caused a surge in the number of COVID-19 cases in December despite an ongoing lockdown in South England and spread rapidly to the whole country and Ireland (4). A second variant was reported from South Africa, passing through the second peak despite the summer season (5). The third variant was reported from the Amazonas State of Brasil, suffering from a severe second peak of COVID-19 (6). All of these countries had been hit hard during the first peak. Waning immunity from the first peak increased the number of cases, and prolonged infections in immunocompromised persons may have contributed to the emergence of variants. All of these three variants had accumulated mutations more than expected. These variants shared some mutations in common that suggest a convergent evolution driven by immune selective pressure. Although all of these variants spread rapidly to the other countries, the variant from England spread much more rapidly and became the dominant variant in continental Europe and other parts of the world. The variants from South Africa and Brazil failed to gain predominance in those countries that they were introduced to. The epidemiologic and clinical data indicate that, in varying degrees, all variants had gained higher transmissibil-

\author{
Corresponding Author: \\ Kenan Midilli \\ E-mail: \\ kmidilli@gmail.com
}

Received: April 27, 2021 Accepted: April 29, 2021 Published: April 30, 2021

\section{Suggested citation:}

Midilli K. The Impact of SARSCoV-2 variants on Morbidity, Mortality and Effectiveness of Vaccines. Infect Dis Clin Microbiol 2021; 1: 48-51.

DOI: 10.36519/idcm.2021.0044 
ity, capability to escape from previous immunity, and they are associated with higher hospitalisation need and mortality rates within 28 days $(7,8)$. The devastating impacts of these variants on the course and control of the pandemic caused a big concern and prompted the initiation and strengthening of genomic surveillance and screening efforts for variants, especially in developed countries. These efforts and a high level of alertness led to identifying new variants in different parts of the world, fortunately still limited to certain geographic regions. Whereas the variants considered dangerous have been described as variants of concerns (VOCs), other variants have been considered less dangerous as variants of interest (VOIs) (Table 1 \& 2). Many organisations and national/international institutions (such as WHO, ECDC, CDC) released guidelines and recommendations to limit the spread of the variants and prevent or avoid the unfavourable effects (9-11).

The emergence of the variants superimposed with the initiation of vaccination in several countries. The potential of the variants to evade immunity acquired through previous infection and vaccination is another subject of concern and is still being investigated extensively. Laboratory investigations indicate that some mutations in the $\mathrm{S}$ gene of the virus are associated with a decline in the effectiveness of antibodies elicited by previous variants and vaccines with an early use authorisation, which can put the efficacy of the vaccines at risk. Although the results have shown the mutations in the receptor-binding domain (RBD) of S protein like E484K change shared by some VOCs and VUIs confers resistance against neutralising activity of anti-

Table 1. Summary of characteristics of VOCs. $(12,17,18,19,20)$

\begin{tabular}{|c|c|c|c|}
\hline & $\begin{array}{l}\text { 501Y.V1 (B.1.1.7; } \\
\text { VOC 202012/01) }\end{array}$ & $\begin{array}{l}\text { 501Y.V2 (B.351; } \\
\text { VOC 202012/02) }\end{array}$ & $\begin{array}{l}\text { 501Y.V3 (B.1.28.1; P1; } \\
\text { VOC 202101/01) }\end{array}$ \\
\hline First emerged in: & England & South Africa & Manaus State, Brasil \\
\hline First deteced in: & September 2020 & August 2020 & November 2020 \\
\hline Detected in & 139 countries & 87 countries & 54 countries \\
\hline Number of spike mutations & 9 & 5 & 11 \\
\hline Characteristic mutations & $\begin{array}{l}\text { H69/V70 del, Y144 del, } \\
\text { N501Y, A570D, P681H, } \\
\text { S106/G107/F108 del }\end{array}$ & $\begin{array}{l}\text { L242/A243/L244 del, K417N, } \\
\text { E484K, N501Y, } \\
\text { S106/G107/F108 del }\end{array}$ & $\begin{array}{l}\text { K417T, E484K, N501Y, } \\
\text { S106/G107/F108 del }\end{array}$ \\
\hline Transmissibility & increased: x 1.4-1.7 & increased: x1.5 & increased: $\times 14-2.2$ \\
\hline Risk of hospitalisation & increased: x1.7 & increased: x 3.6 & increased: x2.6 \\
\hline Need for ICU care & increased: $\times 2.3$ & increased: x 3.3 & increased: x 2.2 \\
\hline Risk of death & increased: x1.3-1.66 & $?$ & increased? \\
\hline Reinfection & ?; reported & ?; reported & up to $40 \%$ \\
\hline $\begin{array}{l}\text { Neutrasitaion by convelescent } \\
\text { plasma (non-VOC) }\end{array}$ & $\begin{array}{l}\text { Yes } \\
\text { decreased about } \times 2\end{array}$ & $\begin{array}{l}\text { Yes } \\
\text { decreased about } x 9\end{array}$ & $\begin{array}{l}\text { Yes } \\
\text { decreased about } x 6\end{array}$ \\
\hline $\begin{array}{l}\text { Effectiveness of the vaccines } \\
\text { (protection by most of vaccines } \\
\text { is retained in all VOCs) }\end{array}$ & slightly decreased $x<2$ & is decreased up to $x 12$ & is decreased up to $\times 10$ \\
\hline
\end{tabular}


Table 2. Summary of characteristics of VOls $(17,18,19,20)$.

\begin{tabular}{|c|c|c|c|c|c|c|c|}
\hline & B.427/429 & B.1.1.28.2 (P2) & B. 525 & B.526/526.1 & B.617 & B..1.1.28.3 (P3) & B. 616 \\
\hline Detected first in: & $\begin{array}{l}\text { California- USA } \\
\text { June } 2020\end{array}$ & $\begin{array}{l}\text { Brasil } \\
\text { April } 2020\end{array}$ & $\begin{array}{l}\text { Nigeria-UK } \\
\text { December } 2020\end{array}$ & $\begin{array}{l}\text { New York -USA } \\
\text { November } 2020\end{array}$ & $\begin{array}{l}\text { India } \\
\text { October } 2020\end{array}$ & $\begin{array}{l}\text { Philippines, Japan } \\
\text { February } 2021\end{array}$ & $\begin{array}{l}\text { France } \\
\text { January } 2021\end{array}$ \\
\hline Spike mutations & $\begin{array}{l}\text { S13I, W152C, } \\
\text { L452R, D614C }\end{array}$ & $\begin{array}{l}\text { E484K, (F565L), } \\
\text { D614G, V1176F }\end{array}$ & $\begin{array}{l}\text { Q52R, A67V, } \\
\text { 69/70del, } \\
\text { 144del, E484K, } \\
\text { D614G, Q677H, } \\
\text { F888L }\end{array}$ & $\begin{array}{l}\text { L5F, T95I, } \\
\text { D253G, D614G, } \\
\text { A701V, E484K } \\
\text { or S477N }\end{array}$ & E484Q, L452R & $\begin{array}{l}\text { 141/143del, } \\
\text { E484K, N501Y, } \\
\text { D614G P681H, } \\
\text { E1092K, H1101Y, } \\
\text { V1176F }\end{array}$ & $\begin{array}{l}\text { H66D, G142V, } \\
\text { 144del, D215G, } \\
\text { V483A, D614G, } \\
\text { H655Y, G669S, } \\
\text { Q949R, } \\
\text { N1187D }\end{array}$ \\
\hline $\begin{array}{l}\text { Transmissibility and } \\
\text { immunevasion }\end{array}$ & $\begin{array}{l}\text { Transmissibility } \\
\text { X } 1.2 \\
\text { Neutralization } \\
\text { by convalescent } \\
\text { and post- } \\
\text { vaccination } \\
\text { sera: decreased }\end{array}$ & $\begin{array}{l}\text { Neutralization } \\
\text { by post- } \\
\text { vaccination } \\
\text { sera: decreased }\end{array}$ & $\begin{array}{l}\text { Neutralization } \\
\text { by convalescent } \\
\text { and post- } \\
\text { vaccination } \\
\text { sera: decreased }\end{array}$ & $\begin{array}{l}\text { Neutralization } \\
\text { by convalescent } \\
\text { and post- } \\
\text { vaccination } \\
\text { sera: decreased }\end{array}$ & $\begin{array}{l}\text { Transmissibiility } \\
\text { is possible } \\
\text { increased. } \\
\text { Neutralization } \\
\text { by post- } \\
\text { vaccination } \\
\text { sera: decreased }\end{array}$ & $?$ & $?$ \\
\hline
\end{tabular}

bodies, fortunately, despite the resistance, vaccines are still effective against current circulating VOCs and VUIs. Also, real-life data support the effectiveness of at least mRNA vaccines against circulating variants (12-14).

Broad vaccination in the shortest period is still considered the most effective way to mitigate the pandemic and stop the emergence of new variants. However, there are still many unknowns about the protective level of neutralising antibodies, risk of reinfection, duration of the immunity induced either by natural infection or vaccination, the role of T-cell responses and memory cells in the effectiveness of protection. Another subject of concern is the potential of the emergence of more resistant, more transmissible, more virulent variants, and the protective immunity conferred by vaccines may be lost with the waning immunity or suboptimal immune responses. To counteract these risk, redesign or tweaking of current vaccines are being considered. Another alternative is to develop pan-coronavirus vaccines that should elicit antibodies against more conserved regions instead of the RBD region, which is much more prone to immune selective pressure. In the near future, in addition to vaccination programs, efforts to decrease the number of infections and to conduct effective, comprehensive genomic surveillance and screening for variants should be prioritised (14-20).
Peer-review: Externally peer-reviewed

Conflict of Interest: The author has no conflict of interest to declare.
Financial Disclosure: The author declared that this study has received no financial support. 


\section{REFERENCES}

1 Arora P, Pöhlmann S, Hoffmann M. Mutation D614G increases SARS-CoV-2 transmission. Sig Transduct Target Ther 2021; 6: 101.

2 Centers for Disease Control and Prevention (CDC). SARSCoV-2 Variant Classifications and Definitions. 2021 Apr 27 (cited 2021 Apr 27). Available from: https://www.cdc.gov/ coronavirus/2019-ncov/cases-updates/variant-surveillance/ variant-info.html

3 Di Caro A, Cunha F, Petrosillo N, Beeching NJ, Ergonul O, Petersen E, et al. SARS-CoV-2 escape mutants and protective immunity from natural infections or immunizations. Clini Microbiol Infect 2021: S1198-743X(21)00146-4. [Epub ahead of print]

4 Public Health England. Investigation of novel SARS-CoV-2 variant. Variant of Concern 202012/01. 2020 Dec (cited 2021 Apr 27). Available from: https://assets.publishing.service.gov. uk/government/uploads/system/uploads/attachment data/ file/959361/Technical_Briefing_VOC202012-2_Briefing_2.pdf

5 Tegally H, Wilkinson E, Giovanetti M, Iranzadeh A, Fonseca $\mathrm{V}$, Giandhari J, et al. Emergence and rapid spread of a new severe acute respiratory syndrome-related coronavirus 2 (SARS-CoV-2) lineage with multiple spike mutations in South Africa. medRxiv 2020.12.21.20248640.

6 Sabino EC, Buss LF, Carvalho MPS, Prete CA Jr, Crispim MAE, Fraiji NA, et al. Resurgence of COVID-19 in Manaus, Brazil, despite high seroprevalence. Lancet 2021; 397: 452-5.

7 Faria NR, Mellan TA, Whittaker C, Claro IM, Candido DDS, Mishra S, Crispim MAE, et al. Genomics and epidemiology of the P.1 SARS-CoV-2 lineage in Manaus, Brazil. Science 2021: eabh2644. [Epub ahead of print]

8 Dejnirattisai W, Zhou D, Supasa P, Liu C, Mongkolsapaya J, Ren J, et al. Antibody evasion by the P.1 strain of SARS-CoV-2. Cell 2021: S0092-8674(21)00428-1. [Epub ahead of print]

9 World Health Organization (WHO). SARS-CoV-2 genomic sequencing for public health goals: interim guidance, 8 January 2021. 2021 (cited 2021 Apr 27). Available from: https://apps. who.int/iris/handle/10665/338483

10 European Centre for Disease Prevention and Control (ECDC). Sequencing of SARS-CoV-2 - first update. 2021 Jan 18 (cited 2021 Apr 27). Available from: https://www.ecdc.europa.eu/en/ publications-data/sequencing-sars-cov-2
11 Centers for Disease Control and Prevention (CDC). Genomic Surveillance for SARS-CoV-2 Variants. 2021 (cited 2021 Apr 27). Available from: https://www.cdc.gov/coronavirus/2019-ncov/cases-updates/variant-surveillance.html

12 Huang B, Dai L, Wang H, Hu Z, Yang X, Tan W, et al. Serum sample neutralisation of BBIBP-CorV and ZF2001 vaccines to SARS-CoV-2 501Y.V2. Lancet microbe 2021. doi: https://doi. org/10.1016/S2666-5247(21)00082-3. [Epub ahead of print]

13 Jangra S, Ye C, Rathnasinghe R, Stadlbauer D; Personalized Virology Initiative study group, Krammer F, et al. SARSCoV-2 spike E484K mutation reduces antibody neutralisation. The Lancet 2021. doi: https://doi.org/10.1016/S26665247(21)00068-9.

14 GAVI. Could COVID-19 vaccines be tweaked to cover new coronavirus variants? 2021 Jan 14 (cited 2021 Apr 27). Available from: https://www.gavi.org/vaccineswork/ could-covid-19-vaccines-be-tweaked-cover-new-coronavirus-variants?gclid=Cj0KCQjwsqmEBhDiARIsANV8H3Yyc4qCoe_CJNoQOux8MMc_4Mu5w6KiATctu4eODEFDgOQwJ9DlrpgaAj yEALw wcB

15 Cohen J. The dream vaccine. Science 2021; 372: 227-31.

16 Altmann DM, Boyton RJ, Beale R. Immunity to SARS-CoV-2 variants of concern. Science 2021: 1103-4

17 Funk T, Pharris A, Spiteri G, Bundle N, Melidou A, Carr M, et al. Characteristics of SARS-CoV-2 variants of concern B.1.1.7, B.1.351 or P.1: data from seven EU/EEA countries, weeks 38/2020 to 10/2021. Euro Surveill 2021: 26: 2100348.

18 World Health Organization (WHO). Weekly epidemiological update on COVID-19 - 27 April 2021. 2021 Apr 27 (cited 2021 Apr 27). Available from: https://www.who.int/publications/m/ item/weekly-epidemiological-update-on-covid-19---27-apr il-2021\#: :text=Globally\%2C\%20new\%20COVID\%2D19\%20 cases, $87 \% 20000 \% 20$ new $\% 20$ deaths\%20reported.

19 Centers for Disease Control and Prevention (CDC). SARSCoV-2 Variant Classifications and Definitions. 2021 Apr 27 (cited 2021 Apr 27). Available from: https://www.cdc.gov/ coronavirus/2019-ncov/cases-updates/variant-surveillance/ variant-info.htm

20 Mullen JL, Tsueng G, Latif AA, Alkuzweny M, Cano M, Haag E, et al. Outbreak.info. 2020 (cited 2021 Apr 27). Available from: https://outbreak.info/ (2020) 